\title{
New Developments for Optimal Management of Head and Neck Cancer
}

Squamous cell carcinomas comprise more than $90 \%$ of the cancers of the head and neck. It is a disease predominately of males with a peak incidence around 60 years, but incidence in young adults is increasing. World-wide, more than 500,000 new cases are projected annually, and this incidence is rising. It is particularly common in parts of Asia, Europe and South America. Head and neck squamous cell carcinoma (HNSCC) accounts for approximately $5 \%$ of all newly diagnosed malignant neoplasms in Western Europe and the United States. In Europe HNSCC is the fourth cancer among males [1]. About one third of the patients presents with early-stage disease (stage I and II), while two thirds present with advanced-stage disease (stage III and IV).

Patient and tumor factors dictate optimal treatment. Since the number of treatment options increases, correct diagnosis and patient selection becomes more and more important. It is therefore not surprising that currently many efforts are directed to the development of more reliable diagnostic techniques to come to optimal and more individualized treatment.

\section{Carcinogenesis}

The main risk factors for development of HNSCC are tobacco and alcohol abuse, but viral infection may also contribute to the development of certain subtypes. Genetic predisposition underlying the sensitivity plays a role in HNSCC development, but to what extent and exactly how remains to be elucidated. Epstein-Barr virus infection is involved in the development of undifferentiated nasopharyngeal carcinoma and is responsible for the endemic presentation of this tumor in Asia and Northern Africa. In Caucasians the tumor type at this site is more often squamous cell carcinoma. Therefore, other factors may be involved in the carcinogenesis of nasopharyngeal cancer and other therapeutic strategies may be mandatory in
Caucasians. It is therefore important that Dietz et al. [2] attempt a more specific diagnostic characterization of nasopharyngeal carcinomas in a German population.

Besides avoidance of toxic substances, chemoprevention has been used as another strategy to reduce the incidence and mortality of HNSCC. Its goal is to halt or even reverse carcinogenesis which progresses as a multistep process characterized by an increasing accumulation of genetic alterations. The most widely used chemoprevention agents are retinoid analogs. These agents appear to regulate gene expression at the nuclear level, possibly interfering with epithelial differentiation and proliferation. Unfortunately, these agents appeared not to be as effective as had been hoped for and to harbor a significant toxicity [3]. Therefore, it is of importance to identify patients who are at high risk for development of HNSCC. The determination of genetic predisposition (mutagen sensitivity) and the identification of pre-cancerous fields in the mucosa of the upper aerodigestive tract are diagnostic options for identification of patients who may benefit from chemoprevention, or reversal of the genetic progression, e.g. through gene therapy.

The realization that many, if not all, HNSCC are preceded by precursor lesions opens new possibilities for early diagnosis and intervention. Clinical investigations are, however, hampered by the fact that the majority of genetically altered fields are clinically invisible and need to be detected with molecular biological techniques. These persisting fields that remain after treatment for head and neck cancer also explain the high incidence of development of second tumors in the same area [4]. Detection and monitoring of these fields may have profound implications for further cancer prevention.

It is thus clear that identification of genes involved in head and neck carcinogenesis, such as investigated by Görögh et al. [5], is of ultimate importance in the development of new avenues in head and neck cancer management.

\begin{tabular}{ll}
\hline KARGER & @ 2004 S. Karger GmbH, Freiburg \\
Fax +49 7614520714 & Accessible online at: \\
$\begin{array}{l}\text { E-mail Information@Karger.de } \\
\text { www.karger.com }\end{array}$ & www.karger.com/onk
\end{tabular}

C. Ren? Leemans, MD, PhD

Dept of Otolaryngology/Head and Neck Surgery

VU University Medical Center (VUmc)

P.O. Box 7057, NL-1007 MB Amsterdam

Tel. +31 20444 36-90, Fax -88

E-mail chr.leemans@vumc.nl 


\section{Primary Tumor}

In most HNSCC patients symptoms at presentation are caused by the site and extent of the primary tumor. The precise extension of the primary tumor is generally determined by panendoscopy (under general anesthesia) and imaging techniques, e.g., computed tomography (CT) or magnetic resonance imaging (MRI).

In case of neck node metastases of an unknown primary squamous cell carcinoma after thorough work-up, treatment usually consists of a neck dissection and irradiation of the neck and the laryngeal-pharyngeal axis. Since this results in severe morbidity, every effort should be made to locate the primary because then an individually tailored treatment can be applied. Positron emission tomography using ${ }^{18} \mathrm{~F}$-fluorodeoxyglucose (FDG-PET) appears to be a more sensitive, selective, and decisive technique for detecting unknown primary tumors than conventional diagnostic techniques [6].

Early-stage disease is usually treated by surgery or radiotherapy, whereas advanced-stage disease is often treated with combined treatment. Since not only cure but also organ preservation is important for maintaining quality of life, carefully selected patients with advanced lesions may be successfully treated initially by irradiation, with surgery reserved for salvage. It has to be remembered that these heavy protocols need to be administered within the setting of a clinical trial in specialized multidisciplinary institutions. With the emphasis on preservation of organ and function, investigational treatment regimens using altered fractionation schedules of radiation and the combination of chemotherapy and radiation have recently emerged [7].

It is currently impossible to predict if non-surgical treatment will yield a complete response. Therefore, Rudat et al. [7] state: 'Predictive tests to successfully stratify patients for the optimal treatment option and more effective systemic therapy are desired to improve the therapeutic ratio and survival.' To this end, several tumor characteristics have been analyzed and related to clinical outcome in HNSCC patients treated with radiotherapy. Some prognostic factors like p53 and epidermal growth factor receptor status have emerged, especially within larynx preservation protocols $[8,9]$.

Differentiating between recurrent carcinoma and significant morbidity following radiotherapy may be a difficult clinical problem, especially in laryngeal carcinoma. These post-radiotherapy changes include edema and necrosis. The need for biopsy itself can present a dilemma as this may exacerbate post-radiotherapy changes, although if clinical suspicion of recurrence exists a biopsy needs to be performed. It has been shown that FDG-PET is able to distinguish tumor recurrence from radiation-associated changes in patients treated for laryngeal carcinoma. It can be anticipated that FDG-PET may avoid futile direct laryngoscopies under general anesthesia and detect recurrences in an early stage in patients with suspicion on recurrent laryngeal carcinoma after radiotherapy [10].
Early detection of recurrent laryngeal carcinoma is an important prognostic factor. Moreover, early detection of recurrence opens the way for partial laryngectomy as an option for salvage treatment in selected cases.

In the past decades progress has been made in the surgical treatment of advanced HNSCC, especially within the realm of reconstructive procedures. Microvascular reconstructive surgery using free vascularized flaps enables resections that were previously impossible and often lead to improved function and quality of life compared to older methods. In HNSCC patients undergoing major surgery with microvascular reconstruction, comorbidity appears to be of great importance for prediction of postoperative complications. Determination of comorbidity grades in these patients may contribute to better counseling and selection of treatment [11].

Among the newer strategies being explored for the treatment of (functionally) inoperable advanced HNSCC is the use of supradose selective intra-arterial chemotherapy (e.g., with cisplatin) with systemic rescue and concurrent radiotherapy. Acronymed 'RADPLAT', this novel therapeutic approach yields acceptable toxicity, high locoregional tumor control, and acceptable survival results [12].

\section{Lymph Node Metastases}

Since the status of the cervical lymph nodes is the single most important tumor-related prognostic factor, it is of great importance for optimal treatment planning to know the exact involvement of the neck nodes [13]. It is well known that assessment of the neck nodes is inaccurate and histopathological evaluations have demonstrated that both the false-positive rate and the false-negative rate are unsatisfactorily high, causing over- and undertreatment in many patients. Modern imaging techniques, such as CT, MRI, Ultrasound (US), and especially US-guided fine-needle aspiration cytology are more reliable than palpation [14]. The capability of all of the above mentioned techniques to detect small tumor deposits (micrometastases) is limited.

New approaches like the use of FDG-PET and imaging using radiolabeled monoclonal antibodies directed against tumorassociated antigens proved not to be superior to conventional imaging techniques $[15,16]$. Some hope exists that a strategy that combines PET with monoclonal antibodies labeled with a positron emitter may be superior [16].

There is general agreement that treatment of the neck is indicated when there are clinically detectable lymph node metastases and when the neck needs to be entered for surgical treatment of the primary tumor and reconstruction. However, as addressed by Dünne et al. [17], controversies remain about the management of the N0 neck. The N0 neck is at risk of harboring occult metastases and is often treated electively if this risk is considered to be above $20 \%$. However, elective neck dissections cause overtreatment for the majority of these pa- 
tients. Another strategy is watchful waiting and delayed neck dissection for patients who develop metastases in the neck. The choice between these strategies mainly arises in the smaller (T1 and T2) carcinomas of the oral cavity and oropharynx, because these tumors usually can be excised adequately by the transoral route without entering the neck. Transoral excision of these tumors, followed by a wait-and-see policy with frequent ultrasonography and US-guided fine-needle aspiration with cytological examination of lymph nodes in the neck is justified to prevent elective neck dissection in these patients [18]. Sentinel lymph node biopsy, in Europe pioneered by the head and neck services of Canniesburn Hospital, Glasgow and the Philipps University in Marburg, has recently been proposed as another alternative for avoiding elective lymph node dissection $[19,20]$. Careful immunohistochemical examination of the node can direct the surgeon to a tailored approach of performing a neck dissection only in those patients that need it. Yet another approach to reduce the number of elective neck dissections is identification of patients at high risk of occult lymph node metastases. Traditional risk factors, such as site and stage of the primary tumor, but also tissue and/or serum-related markers may be helpful to identify high-risk patients [17].

\section{Distant Metastases}

The detection of distant metastases at the time of initial evaluation influences the prognosis and the selection of treatment modality in HNSCC patients. Lungs, bone and liver are the most frequently involved sites. Patients with (clinically detected) distant metastases are generally not considered curable and often receive only supportive or palliative treatment. Extensive nodal involvement (three or more lymph node metastases, bilateral lymph node metastases, lymph nodes of $6 \mathrm{~cm}$ or larger, low jugular lymph node metastases, regional recurrence) is the major risk factor for the development of distant metastases. Because almost all of the patients with distant metastases have metastases in the thorax, a CT scan of the thorax is considered to be the single most important technique for screening for distant metastases in HNSCC patients. During follow-up of patients with initially negative screening approximately $20 \%$ still developed distant metastases. Therefore, probably a significant number of (subclinical) distant metastases remained undetected during initial screening and a more sensitive technique is needed. FDG-PET can detect distant metastases and may be superior to CT scan in this setting [21].
Recent developments in immunology and molecular biology make it possible to detect single tumor cells in body fluids. For these purposes epithelial antigens such as cytokeratins or other tumor-associated antigens are exploited for detection of disseminated tumor cells. The presence of disseminated micrometastatic cells in bone marrow at the time of primary treatment was shown to be related with early relapse and a significantly shorter disease-free survival [22]. Using these diagnostic techniques, patients harboring minimal residual disease and at risk for development of distant metastases can be identified. An effective adjuvant systemic treatment for remaining minimal residual disease is therefore needed to improve survival rates in this patient group. Among the novel approaches for selective systemic treatment is the use of monoclonal antibodies conjugated with radionuclids (radioimmunotherapy) or other cytotoxic agents [23].

\section{Outcome}

For determination of the optimal treatment comparison of outcome parameters is essential. Traditional outcome parameters include complication rate, disease-free survival and disease-specific survival. Non-traditional outcome parameters are becoming increasingly important. Information about objective functioning and patient's perspective can be obtained using specific tests for swallowing (videofluoroscopy) and speech, and quality-of-life instruments (e.g., the EORTC QLQ C30 and H\&N 35, the FACT and the University of Washington questionnaires). Based on these outcome parameters it appears that using microvascular reconstruction in patients with advanced HNSCC results in a generally reasonable function resulting in a very acceptable quality of life, albeit with several distinct problems to cope with. More understanding and improvement in this field is expected over the coming decades.

It is obvious that extensive research is ongoing in the fields of diagnosis and treatment of HNSCC. Molecular biology, imaging techniques and clinical evaluation of treatment strategies may all contribute to better treatment outcome in HNSCC patients. Jochen Werner has to be commended for having been able to assemble several first-class German researchers to contribute to this special issue of ONKOLOGIE on ear nose and throat/head and neck tumors.

R. de Bree, C. R. Leemans, Amsterda

\section{References}

1 Vokes EE, Weichselbaum RR, Lippman SM, Hong WK: Head and neck cancer. N Engl J Med 1993; 328:184-194.
2 Dietz A, Logothetis CA, Helbig M, Fletchenmacher C, Rudat V, Dollner R, Wallner F, Bosch FX: Prognostic impact of EBV-related LMP-1, histologic type, and environmental factors in nasopharyngeal carcinoma in a German population. Onkologie 2004;27:345-350.
3 Glover KY, Papadimitrakopoulou VA: Chemoprevention of head and neck cancer. Curr Oncol Rep 2003;5:152-157. 
4 Braakhuis BJ, Tabor MP, Leemans CR, van der Waal I, Snow GB, Brakenhoff RH: Second primary tumors and field cancerization in oral and oropharyngeal cancer: Molecular techniques provide new insights and definitions. Head Neck 2002;24:198-206.

5 Görögh T, Berwig J, Sola N, Lippert BM: Differential regulation of MAPK (JNK 3) gene expression in human head and neck squamous cell carcinoma. Onkologie 2004;27:353-357.

6 Regelink G, Brouwer J, Bree R de, Pruim J, Laan BFAM van der, Vaalburg W, Hoekstra OS, Comans EFI, Vissink A, Leemans CR, Roodenburg JLN: Detection of unknown primary tumours and distant metastases in patients with cervical metastases: Value of FDG-PET versus conventional modalities. Eur J Nucl Med 2002;29:1024-1030.

7 Rudat V, Pfreunder L, Hoppe F, Dietz: Approaches to preserve the larynx function in locally advanced laryngeal and hypopharyngeal cancer. Onkologie 2004;27:368-375.

8 Bradford CR, Zhu S, Wolf GT, Poore J, Fisher SG, Beals T, McClatchey KD, Carey TE: Overexpression of p53 predicts organ preservation using induction chemotherapy and radiation in patients with advanced laryngeal cancer. Department of Veterans Affairs Laryngeal Cancer Study Group. Otolaryngol Head Neck Surg 1995;113:408-412.

9 Ang KK, Andratschke NH, Milas L: Epidermal growth factor receptor and response of head-and-neck carcinoma to therapy. Int J Radiat Oncol Biol Phys 2004:58:959-965.

10 Terhaard CH, Bongers V, van Rijk PP, Hordijk GJ: F-18-fluoro-deoxy-glucose positron-emission tomography scanning in detection of local recurrence after radiotherapy for laryngeal/pharyngeal cancer. Head Neck 2001;23:933-941.

11 Borggreven PA, Kuik DJ, Quak JJ, de Bree R, Snow GB, Leemans CR: Comorbid condition as a prognostic factor for complications in major surgery of the oral cavity and oropharynx with microvascular soft tissue reconstruction. Head Neck 2003:25:808-815.

12 Kumar P, Robbins KT: Treatment of advanced head and neck cancer with intraarterial cisplatin and concurrent radiation therapy: The 'RADPLAT' Protocol Curr Oncol Rep 2001;3:59-65.

13 Leemans CR, Tiwari R, Nauta JJ, van der Waal I, Snow GB: Regional lymph node involvement and its significance in the development of distant metastases in head and neck carcinoma. Cancer 1993;71: 452-456.

14 Brekel MWM van den, Castelijns JA, Stel HV, Golding RP, Meyer CJ, Snow GB: Modern imaging techniques and ultrasound guided aspiration cytology for the assessment of the neck node metastases: A prospective comparative study. Eur Arch Otorhinolaryngol 1993;250:11-17.

15 Brouwer J, de Bree R, Comans EFI, Castelijns JA, Hoekstra OS, Leemans CR: Positron emission tomography using [18F]fluorodeoxyglucose (FDG-PET) in the clinically negative neck: Is it likely to be superior? Eur Arch Otorhinolaryngol 2003, DOI 10.1007/s00405-003-0727-3 (Epub ahead of print).

16 de Bree R, Roos JC, Verel I, van Dongen GAMS, Snow GB: Radioimmunodiagnosis of lymph node metastases in head and neck cancer. Oral Diseases 2003 ; 9:241-248.

17 Dünne AA, Budach VG, Wagner W, Werner JA: Management of N0 neck in head and neck cancer: Current controversies. Onkologie 2004;27:363-367.

18 Nieuwenhuis EJC, Castelijns JA, Pijpers R, van den Brekel MWM, Brakenhoff RH, van der Waal I, Snow GB, Leemans CR: Wait-and-see policy for the N0 neck in early stage oral and oropharyngeal SCC using ultrasonography-guided cytology: Is there a role for identification of the sentinel node? Head Neck 2002;24:282-289.

19 Shoaib T, Soutar DS, MacDonald DG, Camilleri IG, Dunaway DJ, Gray HW, McCurrach GM, Bessent RG, MacLeod TI, Robertson AG: The accuracy of head and neck carcinoma sentinel lymph node biopsy in the clinically N0 neck. Cancer 2001; 91:2077-2083.

20 Werner JA, Dunne AA, Ramaswamy A, Folz BJ, Lippert BM, Moll R, Behr T: Sentinel node detection in N0 cancer of the pharynx and larynx. Br J Cancer 2002;87:711-715

21 de Bree R, Brouwer J, Comans EFI, Hoekstra OS, Snow GB, Leemans CR: The preliminary results of FDG-PET in screening for distant metastases and synchronous primary tumors below the clavicles in patients with head and neck cancer at initial evaluation; in Lippert BM, Werner JA (eds): Metastases in Head and Neck Cancer. Proceedings of the 2nd International Symposium. Marburg, Tectum, 2001, pp 155-159.

22 Wollenberg B, Walz A, Kolbow K, Pauli C, Chaubal S, Andratschke M: Clinical relevance of circulating tumor cells in the bone marrow of patients with SCCHN Onkologie 2004;27:358-362.

23 Colnot DR, Quak JJ, Roos JC, de Bree R, Wilhelm AJ, Snow GB, van Dongen GAMS: Radioimmunotherapy in patients with head and neck squamous cell carcinoma: Initial experience. Head Neck 2001; 23:559-565.

\section{Impressum}

Die Zeitschrift erscheint zweimonatlich; pro Jahr erscheint 1 Band zu je 6 Heften. Mitglieder der Deutschen Gesellschaft für Hämatologie und Onkologie sowie der Österreichischen Gesellschaft für Hämatologie und Onkologie erhalten die Zeitschrift im Rahmen ihrer Mitgliedschaft. Der Bezug ist im Rahmen des Mitgliedsbeitrags abgegolten. Bezugspreise für Jahrgang 27, 2004: Print-Abonnement EUR 156,-, Online-Abonnement EUR 156,-, Kombi-Abonnement Print/Online EUR 189,-, einschließlich MWSt., zuzüglich Postgebühren. Der Abonnementpreis ist im voraus zahlbar. Das Abonnement der Zeitschrift läuft weiter, wenn es nicht spätestens 4 Wochen vor Abschluss eines Bandes abbestellt wird. Abonnementbestellungen können bei jeder Buchhandlung oder direkt beim Verlag aufgegeben werden:

\section{Deutschland:}

S. Karger Verlag für Medizin und

Übrige Länder:

Naturwissenschaften $\mathrm{GmbH}$

Lörracher Str. 16a

D-79115 Freiburg

Tel. +49761452070

Fax +497614520714

E-mail Information@Karger.de

S. Karger AG

Allschwilerstr. 10

Postfach

CH-4009 Basel

Tel. +416130611 11

Fax +41613061234

E-mail Karger@Karger.ch

Anzeigen:

S. Karger Verlag für Medizin und Naturwissenschaften $\mathrm{GmbH}$

Lörracher Str. 16a, D-79115 Freiburg,

Tel. +49761452070

Gültig ist die Preisliste Nr. 14 vom 1. Januar 2004.

Für den Inhalt außerhalb des redaktionellen Teiles (insbesondere Anzeigen, Industrieinformationen, Pressezitate und Kongressinformationen) übernehmen Schriftleitung, Beirat und Verlag keine Gewähr. Eine Markenbezeichnung kann warenzeichenrechtlich geschützt sein, auch wenn bei ihrer Verwendung in dieser Zeitschrift das Zeichen ${ }^{\circledR}$ oder ein anderer Hinweis auf etwa bestehende Schutzrechte fehlen sollte. Für Satzfehler, insbesondere bei Dosierungsangaben, wird keine Gewähr übernommen. Die Zeitschrift sowie alle in ihr enthaltenen einzelnen Beiträge und Abbildungen sind urheberrechtlich geschützt. Jede Verwertung, die nicht ausdrücklich vom Urheberrechtsgesetz zugelassen ist, bedarf der vorherigen Zustimmung des Verlags. Das gilt insbesondere für Vervielfältigungen, Bearbeitungen, Übersetzungen, Mikroverfilmungen und die Einspeicherung und Verarbeitung in elektronischen Systemen.

\section{(C) Copyright 2004 by S. Karger}

Verlag für Medizin und Naturwissenschaften $\mathrm{GmbH}$

Lörracher Str. 16a, D-79115 Freiburg

Verlagsleitung und presserechtlich verantwortlich: Sibylle Hopf

Produktionsleitung: Georg Brunner

Anzeigenleitung: Susanne Meister

Gesamtherstellung:

KONKORDIA GmbH, Bühl

Das Medienunternehmen

Bibliographische Dienste
Biological Abstracts
Current Contents/Clinical Medicine
Excerpta Medica/EMBASE
Index Medicus/MEDLINE
Medical Documentation Service
Reference Update
Research Alert
Science Citation Index
SCISEARCH Database

Mit dieser Ausgabe erscheinen zwei Supplemente: «Oxaliplatin (Eloxatin ${ }^{\circledR}$ ) - Fortschritte in der Tumortherapie 2004». ISBN 3-8055-7825-3, und

«24. Jahrestagung der Deutschen Gesellschaft für Senologie - Abstracts». ISBN 3-8055-7826-1 